BSE repair contracts involved virtually no risk at all, and yet the company has been left with a retained profit of 32 per cent on costs. Not surprisingly, the committee was dissatisfied with this. It also recommended a review of the spare parts contracts entered into in the same period. Mr Wedgwood Benn, Minister of Technology, who could hardly do nothing about a report so critical of his ministry, agreed on July 25 to undertake this review, but declined to reopen the profits inquiry.

\section{No Redundant Geophysicists}

THE future for international geophysical co-operation seems likely to be one of consistent, if more modest, progress than in the past. This has emerged from the meeting of the Committee on Space Research which has been going on in London over the past week. Dr Herbert Friedman, President of the Inter-Union Commission on Solar Terrestrial Physics-which is likely to be charged with the responsibility of maintaining the international programmes-said last week, "The IGY and the IQSY were special efforts-there is no need to generate special efforts now. The problem is to keep programmes up on a continuing basis; we must keep momentum up as long as possible." The inter-union commission consists of Dr Friedman, twelve representatives from different scientific disciplines and representatives from various organizations, including the World Meteorological Organization, the Scientific Committee on Antaretic Research (SCAR), the Scientific Committee on Oceanic Research (SCOR) and the Federation of Astronomical and Geophysical Services (FAGS). "This is a continuing field, and therefore the commission will continue indefinitely," Dr Friedman added. It would not, he said, be a stopgo operation.

At least two of the data centres set up for the IGY and IQSY will remain in existence. These are the $A$ and $B$ centres in Moscow and Boulder, Colorado. There is also a good chance that a number of the $C$ centres will be kept in operation, although this presumably depends on the attitude of the governments supporting them. The $C$ centre at the Radio and Space Research Station at Slough will be one that will keep going. Both Dr Friedman and Professor W. J. G. Beynon, chairman of the organizing committec of the IQSY, were optimistic about the international reaction to collaborative projects. In developed countrics there is no objection, and underdeveloped countries see the projects as an entry ticket to big science. "The motivation is strong to see the programmes continue," Dr Friedman observed.

There is likely, though, to be a change in the emphasis of the programmes. More discriminating experiments are likely to take over from what Dr Friedman described as the "shot-gun" approach adopted so far. He suggested that simultaneous measurements at different points in space-one either side of an auroral curtain, for instance-could provide much uscful information. Although synoptic measurements would be continued, they might well start to concentrate on the inhomogeneities in the atmosphere and the fine scale detail of the ionosphere. The data contres themselves, Dr Friedman hoped, could initiate research on data handling, rather than being merely passive recipients of data.

\section{Going to University}

THE regulations which determine whether young people can get into a British university in 1968 differ most obviously from those now current in their greater bulk. But the Compendium of University Entrance Requirements (published by the Association of Commonwealth Universities for the Committee of Vice-Chancollors and to be had from Percy Lund, Humphries and Co., 14s. 6d.) is also a slightly more liberal document in that there is now a more obvious sprinkling of university departments which do not rigorously specify in advance the qualifications which potential entrants must somehow attain. In a foreword to the document, however, Sir Robert Aitken, Chairman of the Standing Conference on University Entrance, and Sir Charles Wilson, Chairman of the Committee of Vice-Chancellors, promise better things for the succeeding year 1969-70. For by now it is an open secret that the vice-chancellors have been working hard on a document intended to clothe with flesh the bare bones of the policy enunciated several years ago which would have the effect of allowing intending entrants to universities to do so without having spent virtually all their time as seniors at school working on the courses they will later follow at university.

\section{New Zealand Brain Drain}

NEW Zearand's loss of about 40 per cent of a year's output of first class honours graduates cach year to the brain drain makes Britain's loss of about 15 to 20 per cent of all $\mathrm{PhD}$ graduates look small. In the New Zealand National Research Advisory Council publication, Some Aspects of Technical Manpower in New Zealand, it is estimated that the permanent Joss amounts to 67 per cent of first class honours physicists, 48 per cent of first class honours mathematicians, and 35 per cent of first class honours chemists and geologists. New Zealand also loses about 25 per cent of those with a lower level of honours degree. New Zealand's total output of masters and bachelors graduates from 1960 to 1964 was 663 , of whom 242 were first class graduates. In these years there was a total output of 199 chemists, 63 first class honours; 131 mathematicians, 48 first class honours; 102 physicists, 36 first class honours; 69 zoologists, 34 first class honours; 55 geologists, 15 first class honours; 42 agricultural scientists, 16 first class honours; and 35 botanists, 15 first class honours.

The report says that according to the Government Statistician, New Zealand gains more scicntists than it loses, though it in no way confirms the figure. The main problem is the quality and research intercsts of those gained and lost rather than thcir total number. A striking feature of the figures is that there is a comparatively small loss in botanists (4 per cent), agricultural scientists (19 per cent) and zoologists (24 per cent), which confirms that those sciences with strong local links more easily retain good graduates than those which are more independent of the environment.

The report suggests that there is a need to arouse interest in all students in all disciplines in research problems peculiar to New Zealand. While this may require more conscious effort in disciplines such as mathematios and physics than in zoology, for example, it is suggested that this is not impossible. This is, in 